$\xi_{p-1}$

\title{
The holistic work engagement: A study In indonesia oil palm industry
}

\author{
Nopriadi Saputra $^{1 *}$, Sasmoko ${ }^{1}$, Sri Bramantoro Abdinagoro ${ }^{1}$ \\ ${ }^{1}$ Bina Nusantara University \\ *Corresponding author E-mail: nopriadisaputra@yahoo.com
}

\begin{abstract}
Industry 4.0 encourages organizations to implement holistic framework in human resource development. It is imperative to align concept of work engagement into holistic framework. This study aims to conduct confirmatory factor analysis on holistic work engagement concept and was conducted on 477 supervisors and managers from Indonesia oil palm industry. The data was analyzed by using Lisrel 9.30 and the result explains that the measurement model of holistic work engagement has adequate validity and reliability. The measurement model of the higher order construct has better goodness of fit than first order one.
\end{abstract}

Keywords: Work Engagement, Spirituality, Holistic Framework HRD.

\section{Introduction}

The development of internet technology has triggered the fourth industrial revolution or Industry 4.0 and has opened unlimited opportunity for individuals and organizations to collaborate, produce and transact continuously in 24 hours from many places all over the world [1]. Unfortunately, Industry 4.0 also bring us to the world with highly volatile, uncertain, complex, and ambiguous the VUCA world [2, 3].

For effectively dealing with VUCA world, management scholars give two recommendation: (1) developing business agility by utilizing technology $[4,5,6]$ and / or (2) developing of spirituality \& religion at the workplace $[7,8,9,10]$.

Ahmed, Mohd, Arshad, and Sohail [11] explained that a holistic framework in human resources development is an imperative for dealing with highly competitive and rapidly changing business environment. The organization does not only develop intellectual (IQ), and emotional (EQ) aspects; but also concern and develop the spiritual aspect (SQ) of human resources.

The holistic framework is in line with the spirituality movement [12] which is one of the transformational movements in management practice where the organization begins to provide space for the spiritual dimension in management practice. Some big companies like Intel, Coca-Cola, Boeing, and Sears have incorporated the spirituality into their business strategy and corporate culture [13].

Work engagement is one of the most popular management tools. Rigby and Bilodeau [14] reported that work engagement is one of the five management tools which most frequently used by top executives in Asia region and the world. Work engagement was first introduced by William A Kahn [15]. Buckingham and Coffman - through the book entitled "First, Break all the rules!" introduced Q-12 Gallup Questionnaires for measuring engagement levels of employees. This book has made the term employee engagement or work engagement become buzzword among practitioners and scholars in management.
Concept of work engagement can be approached from various theories [16]. This study uses Herzberg two-factor motivation theory; job characteristics theory, and JD-R model [17] as background theories. JD-R model explains that work engagement is increasing when the employee has more job resources than job demands. Bakker and Demerouti [18] refined the JD-R model by adding personal resources as factors which impact on motivational process and work engagement.

In the VUCA world, organization is changing more frequently, faster, and more significantly than in the past. It make human resources need to develop personal resources to continually enhance their capabilities and work engagement [19]. Personal resources consists of physical, intellectual, emotional and spiritual aspects of human resources [20].

Several empirical studies have proved that spiritual resources is an antecedent of work engagement. Bickerton, Miner, Dowson, and Griffin [21] conclude that spiritual resources is the only predictors of work engagement. Karimi and Karimi [22] proved that spiritual and emotional intelligence have a positive impact - directly or indirectly on work engagement. Petchsawang and McLean [23] concluded that spirituality in the workplace has a positive and significant impact on work engagement.

Based on those arguments, this study realizes that Industry 4.0 has triggered organization to develop human resources in holistic frameworks as well as in the utilizing of work engagement as a management tools. This study aims to develop a holistic concept of work engagement and conduct confirmatory factor analysis either in first and higher order construct.

\section{Literature review}

\subsection{Work engagement}

Bailey, Madden, Alfes, and Fletcher [24] stated that there are six groups of work engagement definitions which most commonly used by researchers: (1) personal engagement; (2) positive \& fulfilling state of mind; (3) job and organizational engagement; (4) 
attitudinal \& behavioural construct composite; (5) engagement as management practice; and (6) self-engagement with performance. Generally work engagement is reflected and measured into three dimensions [24, 25[ 26]. Kahn [15] reflects work engagement into meaningfulness, safety and availability. Maslach, Schaufeli, and Leiter [27] reflects work engagement into: energy, involvement, and efficacy. Schaufeli, Salanova, Gonzalez-Roma, and Bakker [28] reflects work engagement into: vigor, dedication, and absorption.

\subsection{Spirituality at work place}

The progress of spirituality at workplace as newly branch of management theory is indicated by special interest group at The Academy of Management in 2000 which named "The Management, Spirituality and Religion". It is also indicated by the publication of several books such as: Liberating the corporate soul [29], Religion and the workplace [30], Handbook of workplace spirituality and organizational performance [31], and Spirituality in business: Theory, practice, and future directions [32].

According to previous literature review [13, 23, 33, 34], spirituality at work is reflected into four dimensions: (1) transcendence - realizing the presence of the most sacred in the work; (2) calling - making work a means to serve the most sacred by serving others; (3) compassion - a strong desire to be a benefit for the others; and (4) meaningfulness - getting a sense of meaningfulness through work, worship, and social interaction.

\subsection{Holistic work engagement}

Based on holistic framework HRD [20]; intellectual quotient (IQ) is defined as personal ability to attain goals while facing many obstacles by rational decision making. It related with rational ability, knowledge mastery, skills, reasoning, and logic. Emotional quotient (EQ) is related with individual ability to cultivate stress, control emotions, empathy, self-control and conflict handling skills. Spiritual quotient (SQ) is related with self awareness, wisdom, sense of meaning, sense of community, compassion, connectedness, and humanization.

In line with the holistic framework, work engagement may also be viewed from the physical, intellectual, emotional, and spiritual dimensions. The concept of work engagement developed by Kahn [15] is a reflection of the emotional dimension (for safety and availability) and spiritual dimension (for meaningfulness). The concept of work engagement developed by Maslach, Schaufeli, \& Leiter [27] is a reflection of the physical dimension (for energy) and emotional dimension (for involvement and efficacy). Meanwhile, the concept of work engagement developed by Schaufeli et al. [28] is a reflection of the physical dimension (for vigor), the emotional dimension (for dedication) and the intellectual dimension (for absorption).

This study proposes holistic work engagement as the four dimension construct of work engagement concept. Holistic work engagement is reflected into the physically, intellectually, emotionally and spiritually engaged dimension. By using this four dimension construct. it will make easier for management practitioners and scholar to relate the measurement results with the relevant development programs for improving the work engagement in the company.

This study defines holistic work engagement (HWE) as person's self-condition in which the work is fully integrated physically, intellectually, emotionally and spiritually. Physically engaged (PHE) is the willingness and ability of individuals to utilize health (PD01), fitness (PD02), and physical endurance (PD03) to perform work. Intellectually engaged (INE) is the willingness and ability of individuals to utilize the ability of thinking (ID01), creativity (ID02), and focus-concentration (ID03) to perform work Emotionally engaged (EME) is individual's willingness and ability to utilize feelings of pride (ED01), joy (ED02) and dedication (ED03) to perform work. Spiritually engaged (SPE) is the individual's willingness and ability to utilize transcendence (SD01), devotion or calling (SD02), compassion or usefulness for the people (SD03), and the meaningfulness of life (SD04) to perform work.Many studies have shown that the mitigation of temperature measures, such as increasing the quantity of vegetation cover, might alter the severe impact of urbanization. The vegetation provides a cooling effect, mainly through its shadowing effect and evapotranspiration process. The process is basically a natural mechanism in which heat is removed by changing the heat from sensible heat to latent heat. Additionally studies proposed the presence of water body can minimize the UHI effect of an urban area by creating water body cooling island $[9,10,11]$. A similar process like green space is happening over water bodies with the help of solar radiation. This process is known as evaporative cooling. When solar radiation from the sun reaches the water's surface, the water will vaporize and remove the heat, thereby cooling the surrounding air.

Water features within an urban area have a positive effect on the microclimate of the surrounding areas when natural cooling from the evaporative process is needed on hot sunny days. The increased availability of water usually enhances evaporation, and the related uptake of latent heat provides an additional daytime cooling effect. The air temperature near or over bodies of water is much different from that over land due to differences in the way water heats and cools. Water bodies are noted to be about the best absorbers of radiation; on the other hand, they exhibit very little thermal response. Many other researchers have argued that evaporative cooling from water bodies or water features is one of the most efficient ways to passively cool building and urban spaces. However, evaporative cooling might not work optimally in a hot, humid tropical country as it has high relative humidity [12]. Although studies have also mentioned that having more water surfaces could improve the urban heat island effect, this possibility has received comparatively less attention [8].

A study by Murakawa showed a difference of approximately 3 $5^{\circ} \mathrm{C}$ in air temperature between the river and the city area in Japan. The water bodies of the river operate as a cooling source on the microclimate of the surrounding area. Many other researchers have argued that evaporative cooling from water bodies or water features is one of the most efficient ways to provide passive cooling for building and urban spaces [13]. Thus, the current study examines this evaporative cooling performance of water bodies for the surrounding microclimate of Singapore. Ambient air temperatures are measured to make a clear distinction of the influence of cooling from the water bodies horizontally [14]

\section{Research methodology}

\subsection{Sample}

This study used cluster stratified proportional random sampling. Because most of Indonesia palm oil plantation (95.8\%) is located in Sumatra and Borneo, the sample is divided into two clusters Sumatra and Borneo. Agronomy assistants, lead assistants, and estate managers who work for palm oil plantation in Sumatra and Borneo are the respondents of this study There are 15,907 agronomy assistants, lead assistants, and estate managers is estimated as the population. The sample was stratified proportionally based on clusters and structural positions. Data collection is done randomly based on the list of GAPKI members. Based on the population, the expected sample size 376 [35]. This study has collected successfully data from 491 respondents, but 14 respondents did not give responses correctly and completely. Finally the analysis of this study based on 477 respondents. The profile of respondents is dominated by men (85\%); born between 1980 to 1999 (79\%); less five year of work experience in palm oil plantation $(51 \%)$; with bachelor degree as educational background (71\%); come from non-farming family $(80 \%)$, and as team leader or supervisor in the organization $(60 \%)$.

\subsection{Measurement \& procedure}


Covariance Based Structural Equation Modeling (CB-SEM) approach with Lisrel 9.30 is used for data analysis. CB-SEM is more relevant and has robust estimation for confirmatory research than Variance-Based SEM [36]. SEM has two main steps : (1) measurement model analysis and (2) structural model analysis. This study conducted confirmatory factor analysis (CFA) of measurement model by evaluating validity of items, reliability of dimension, and goodness of fit of the measurement model. Validity of items is indicated by standardized factor loading (SFL) more than 0.5 . Reliability of dimension is indicated by construct reliability (CR) more than 0.7 or variance extracted (VE) more than 0.5. Goodness of fit analysis of the model is indicated by $p$ value, RMSEA, NFI, NNFI, CFI, RFI, IFI, Standardized RMR, GFI, and AGFI. CFA is conducted on first order construct and also on second order construct.

\section{Results and discussions}

\subsection{First order construct}

Figure 1 explain that the items in first structure construct have SFL between $0.51-0.79$. Item ID03 was excluded from the model because SFL less than 0.5. Model has 12 items and RMSEA = 0.092 is bigger than 0.008 .

Table 1 explain that the 12 items of model are valid, because SFL of all items are more than 0.5. The variable is reliable, because CR $=0.88$ is bigger than 0.7 , but $\mathrm{VE}=0,39$ is less than 0.50 . The model is reliable and valid for measurement.

\subsection{Second order construct}

Figure 2 shows the second order construct where the variable is reflected into four dimensions. Item ED03 has SFL less than 0.5 and then was excluded from the model. The rest items have SFL between $0.64-1.11$ and it is bigger than in first order construct.
The model also has RMSEA $=0.075$ less than 0.080. It indicates that the model is good fit.

All items are valid, because SFL are more than 0.5 and all dimension are reliable because CR $>0.7$ or VE 0.5. Emotional engaged (EME) dimension is reliable with $\mathrm{CR}=0.93$ and $\mathrm{VE}=0.80$. Intellectually engaged (INE) dimension is reliable with $\mathrm{CR}=0.80$ and $\mathrm{VE}=0.67$. Physically engaged (PHE) dimension is reliable with $\mathrm{CR}=0.72$ and Spiritually engaged $(\mathrm{SPE})$ is reliable too with $\mathrm{CR}=$ 0.84 and $\mathrm{VE}=0.56$.

Table 3 compares the result of goodness of fit analysis between first and second order construct of holistic work engagement. First order construct is good fit with two indicator - Comparative Fit Index (CFI) and Incremental Fit Index (IFI) are more than 0.900. The second order construct is good fit with for indicator RMSEA less than 0.08; CFI and IFI are more than 0.900 and Standardized RMR $=0.05$. Based on above comparison, the goodness fit of second order construct is better than first one.

Figure 2 shows that holistic work engagement of agronomy assistants, lead assistants, and estate managers in Indonesia palm oil plantation is more reflected into spiritual $(90 \%)$ and physical $(88 \%)$ than intellectual $(72 \%)$ and emotional (57\%) dimension.

\section{Conclusion}

For effectively dealing with highly competitive and changing environment, organizations need to align human resource development with holistic framework of thinking. Holistic work engagement is four dimension and second order construct of work engagement. It is defined as person's self-condition in which the work is fully integrated physically, intellectually, emotionally and spiritually. Holistic work engagement in Indonesia palm oil plantation is more reflected into spiritual and physical than intellectual and emotional dimension.

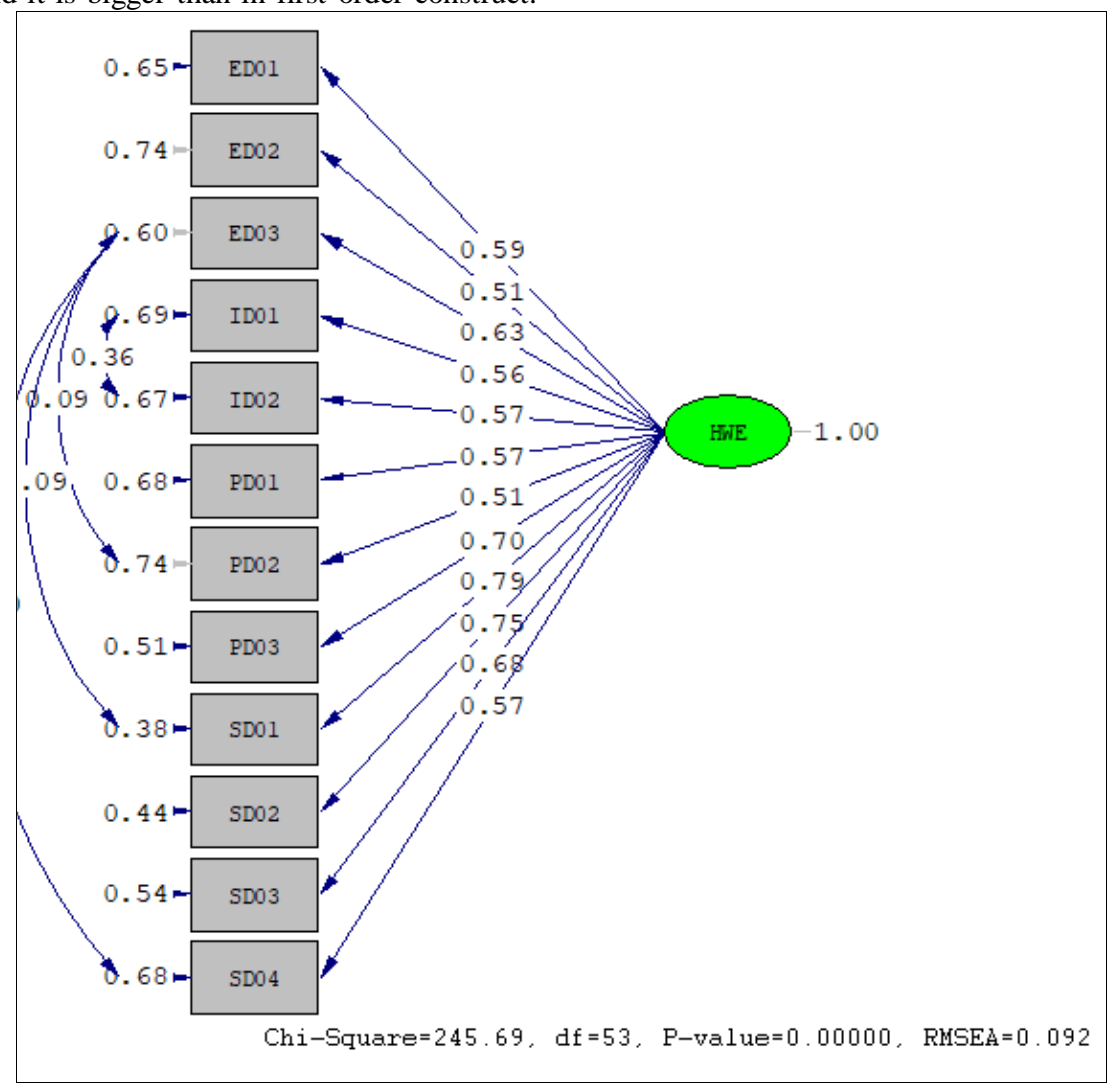

Fig. 1. First Order Construct of Holistic Work Engagement

Table1. Validity \& Reliability Test for First Order Construct

\begin{tabular}{|c|c|c|c|c|}
\hline Item & SFL $>0.5$ & CR $>0.7$ & VE $>0.5$ & Result \\
\hline
\end{tabular}




\begin{tabular}{|c|c|c|c|c|}
\hline \multicolumn{2}{|c|}{ Holistic Work Engagement } & 0.88 & 0.3 & Reliable \\
\hline ED01 & 0.59 & & & Valid \\
\hline ED02 & 0.51 & & & Valid \\
\hline ED03 & 0.63 & & & Valid \\
\hline ID01 & 0.56 & & & Valid \\
\hline ID02 & 0.57 & & & Valid \\
\hline PD01 & 0.57 & & & Valid \\
\hline PD02 & 0,51 & & & Valid \\
\hline PD03 & 0.70 & & & Valid \\
\hline SD01 & 0.79 & & & Valid \\
\hline SD02 & 0,75 & & & Valid \\
\hline SD03 & 0.68 & & & Valid \\
\hline SD04 & 0.57 & & & Valid \\
\hline
\end{tabular}

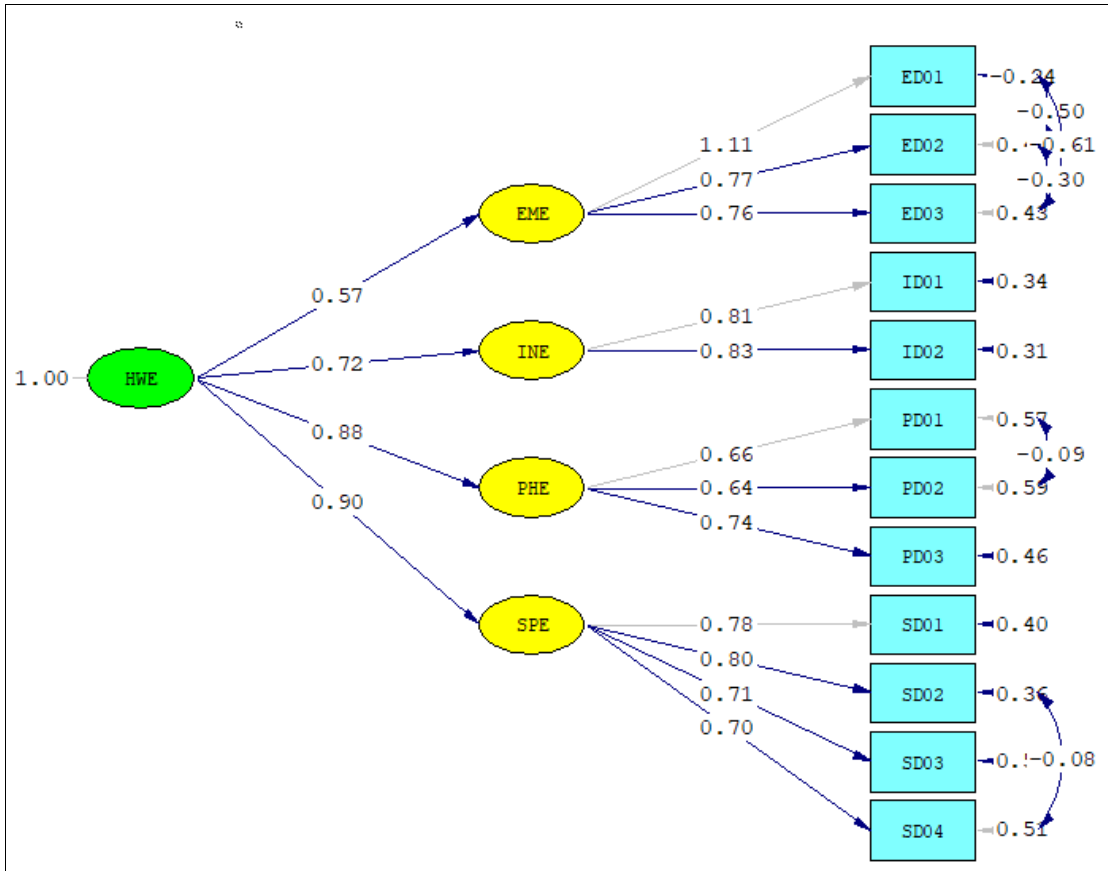

Chi-Square $=310.96, \mathrm{df}=50, \mathrm{P}-\mathrm{value}=0.00000, \mathrm{RMSEA}=0.075$

Fig. 2. Higher Order Construct of Holistic Work Engagement

Table 2. Validity \& Reliability Test for Higher Order Construct

\begin{tabular}{|c|c|c|c|c|}
\hline Dimension / Item & SFL $>0.5$ & $\mathrm{CR}>0.7$ & $\mathrm{VE}>0.5$ & Result \\
\hline \multicolumn{2}{|c|}{ Emotionally Engaged (EME) } & 0.93 & 0.80 & Reliable \\
\hline ED01 & 1.11 & & & Valid \\
\hline ED02 & 0.77 & & & Valid \\
\hline ED03 & 0.76 & & & Valid \\
\hline \multicolumn{2}{|c|}{ Intellectually Engaged (INE) } & 0.8 & 0.67 & Reliable \\
\hline ID01 & 0.81 & & & Valid \\
\hline ID02 & 0.83 & & & Valid \\
\hline \multicolumn{2}{|c|}{ Physically Engaged (PHE) } & 0.72 & 0.46 & Reliable \\
\hline PD01 & 0,66 & & & Valid \\
\hline PD02 & 0,64 & & & Valid \\
\hline PD03 & 0.74 & & & Valid \\
\hline \multicolumn{2}{|c|}{ Spiritually Engaged (SPE) } & 0.84 & 0.56 & Reliable \\
\hline SD01 & 0.78 & & & Valid \\
\hline SD02 & 0.80 & & & Valid \\
\hline SD03 & 0.71 & & & Valid \\
\hline SD04 & 0.70 & & & Valid \\
\hline
\end{tabular}

Table 3. Goodness of Fit Analysis

\begin{tabular}{|c|c|c|c|c|c|}
\hline \multirow{2}{*}{ No } & \multirow{2}{*}{ GOFI Standard } & \multicolumn{2}{|c|}{ First Order } & \multicolumn{2}{c|}{ Higher Order } \\
\cline { 3 - 6 } & & Score & Result & \multicolumn{2}{c|}{ Score } \\
\hline 1 & $p$-value $>0.050$ & 0.000 & Not & 0.000 & Not \\
\hline 2 & RMSEA $<0.080$ & 0.092 & Not & 0.075 & Good Fit \\
\hline 3 & NFI $>0.900$ & 0.882 & Not & 0.878 & Not \\
\hline 4 & NNFI $>0.900$ & 0.881 & Not & 0.873 & Not \\
\hline 5 & CFI $>0.900$ & 0.904 & Good Fit & 0.900 & Good Fit \\
\hline 6 & IFI $>0.900$ & 0.905 & Good Fit & 0.901 & Good Fit \\
\hline 7 & RFI $>0.900$ & 0.853 & Not & 0.845 & Not \\
\hline
\end{tabular}




\begin{tabular}{|c|c|c|c|c|}
\hline 8 & Standardized RMR $<0.050$ & 0.076 & Not & 0.050 \\
\hline 9 & GFI $>0.900$ & 0.831 & Good Fit & 0.896 \\
\hline 10 & AGFI $>0.900$ & 0.751 & Not & Not \\
\hline
\end{tabular}

\section{References}

[1] Devezas T, Leitão J \& Sarygulov A (2017), Industry 4.0: Entrepreneurship and Structural Change in the New Digital Landscape. http://doi.org/10.2861/947880

[2] Bawany S (2016), Leading in a VUCA business environment. Leadership Excellence Essentials 7, 39-40.

[3] Mack O, Khare A, Kramer A \& Burgatz T (2016), Perspectives on a VUCA world. In Managing in a VUCA World 3-19.

[4] Horney N, Pasmore B \& O'Shea T (2010), Leadership Agility: A Business Imperative for a VUCA World. People \& Strategy 32-38.

[5] Prange C (2016), Engaging with complex environments: why agility involves more than running hard. International Journal of Complexity in Leadership and Management 3(3), 182-197.

[6] Weill P, Subramani M \& Broadbent M (2002), IT infrastructure for strategic agility. MIT SLoan School of Management Working Paper 4235-02.

[7] Benefiel M, Fry LW \& Geigle D (2014), Spirituality and religion in the workplace: History, theory, and research. Psychology of Religion and Spirituality 6(3), 175.

[8] Neal J (2013), Handbook of faith and spirituality in the workplace: Emerging reseach and practice. Springer Science+Business Media.

[9] Stead J \& Stead W (2014), Building spiritual capabilities to sustain sustainability-based competitive advantages. Journal of Management, Spirituality \& Religion 11(2), 143-158.

[10] Yasuno BM (2008), The Role of Spirituality in Leadership for Social Change. Spirituality in Higher Education 4(3), 1-8.

[11] Ahmed A, Arshad MA, Mahmood A \& Akhtar S (2016), Spiritual intelligence ( SQ ): A holistic framework for human resource development. Administration and Public Management 26, 60-78.

[12] Ashmos DP \& Duchon D (2000), Spirituality at work: A Conceptualization and Measure. Journal of Management Inquiry 9(2), 134-145.

[13] Karakas F (2010), Spirituality and performance in organization : A literature review. Journal of Business Ethics 94(1), 89-106.

[14] Rigby BD \& Bilodeau B (2015), Management Tools \& Trends.

[15] Kahn WA (1990), Psychological Conditions of Personal Engagement and Disengagement at Work. Academy of Management Journal 33(4), 692-724.

[16] Albrecht SL (2010), Handbook of employee engagement: Perspectives, issues, research and practice (C. L. Cooper, Ed.). Edward Elgar.

[17] Demerouti E, Bakker AB, Nachreiner F \& Schaufeli WB (2001), The job demands-resources model of burnout. The Journal of Applied Psychology. http://doi.org/10.1108/02683940710733115

[18] Bakker AB \& Demerouti E (2008), Towards a model of work engagement. Career Development International 13(3), 209-223.

[19] Imperatori B (2017), Engagement and Disengagement: Drivers and Organizational Practices to Sustain Employee Passion and Performance. Springer. http://doi.org/10.1007/978-3-319-51886-2

[20] Ahmed A, Mohd AA, Arshad M \& Sohail A (2016), Holistic human resource development: Balancing the equation through the inclusion of spiritual quotient. Journal of Management Policy and Practice 17(1), 94-105. http://doi.org/10.1177/0971685816650573

[21] Bickerton GR, Miner MH, Dowson M \& Griffin B (2014), Incremental validity of spiritual resources in the job demandsresources model. Psychology of Religion and Spirituality 7(2), 12.

[22] Karimi Z \& Karimi F (2016), The structural model of relationship between spiritual intelligence and emotional intelligence with quality of work life and work engagement of employees. International Journal of Management in Education 10(3), 278-292.

[23] Petchsawang P \& McLean GN (2017), Workplace spirituality, mindfulness meditation, and work engagement. Journal of Management, Spirituality \& Religion 1-29.

[24] Bailey C, Madden A, Alfes K \& Fletcher L (2015), The meaning, antecedents and outcomes of employee engagement: A narrative synthesis. International Journal of Management Reviews 00, 1-23.

[25] Keyko K, Cummings GG, Yonge O \& Wong CA (2016), Work engagement in professional nursing practice: A systematic review. International Journal of Nursing Studies 61, 142-164.

[26] Wollard KK \& Shuck B (2011), Antecedents to employee engagement: A structured review of the literature. Advances in Developing Human Resources 13(4), 429-446. http://doi.org/10.1177/1523422311431220
[27] Maslach C, Schaufeli WB \& Leiter MP (2001), Job Burnout. Annual Review of Psychology 52, 397-422.

[28] Schaufeli WB, Salanova M, Gonzalez-Roma V \& Bakker AB (2002), The measurement of engagement and burnout: A two sample confirmatory factor analytic approach. Journal of $\begin{array}{llrr}\text { Happiness } & \text { Studies } & \text { 3, }\end{array}$ http://doi.org/10.1023/A:1015630930326

[29] Barret R (2013), Liberating the corporate soul. Routledge.

[30] Hicks DA (2003), Religion and the workplace: Pluralism, spirituality and leadership. Cambridge University Press.

[31] Giacalone RA \& Jurkiewics CL (2003), Handbook of workplace spirituality and organizational performance. Me Sharpe.

[32] Biberman J \& Tischler L (2008), Spirituality in business: Theory, practice, and future directions. Springer.

[33] Milliman J, Czaplewski AJ \& Ferguson J (2003), Workplace spirituality and employee work attitudes. Journal of Organizational Change Management 16(4), 426-447.

[34] Roof RA (2014), The Association of Individual Spirituality on Employee Engagement: The Spirit at Work. Journal of Business Ethics 130(3), 585-599. http://doi.org/10.1007/s10551-014-2246-0

[35] Krejcie RV \& Morgan D (1970), Determining Sample Size for Research Activities. Educational and Psychological Measurement 30, 607-610.

[36] Hair JFJ, Hult GTM, Ringle C \& Sarstedt M (2014), A Primer on Partial Least Squares Structural Equation Modeling (PLS-SEM). Long Range Planning. http://doi.org/10.1016/j.lrp.2013.01.002 